\title{
MAKING VIRTUAL REALITY (VR) A REALITY!
}

\section{Chair: Daniela Souza - Director Marketing of SET - SVP - AD Digital}

The recent development of VR technologies gave wings to all our creative dreams. Content creators are now able to take viewers through an immersive experience with an almost unlimited potential and transport consumers to any place in this or other worlds. Virtual reality is unique, especially when compared to other types of media, in that the viewer's attention is full and exclusively focused on the experience, making for a powerful and lasting impression.

- WHAT IS ALREADY REAL IN VIRTUAL REALITY? Speaker: Renato Citrini - Product Marketing Manager - Samsung

Virtual reality glasses, 360 cameras for the ultimate consumer, smartphone processing capabilities and content for these glasses available on Facebook and YouTube. Where does Virtual Reality go and where are you going?

- IMMERSIVE NARRATIVES: THE PRESENT OF STORYTELLING Speaker: Ricardo Laganaro, Diretor, 02 filmes,

Ricardo Laganaro tells how the immersive narrative is already a reality in telling stories, after producing $360^{\circ}$ movies and virtual reality for big brands, totaling over 60 million views, as well as museums, exhibitions and a short film produced by Oculus with participation in film festivals like Tribeca and Sundance

- GLOBAL VR ECOSYSTEM: WHERE ARE THE BIG OPPORTUNITIES?

Speaker: Marcos Alves, Director of Ventures at YDreams Global

How is the global Virtual Reality market currently organized? Who are the main players and trends, where are the big business opportunities and what could be the next killer-apps. 


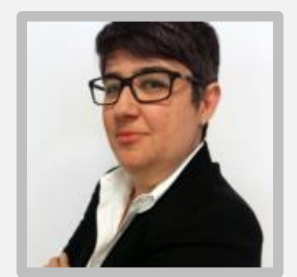

\section{Daniela Souza - Director Marketing of SET - SVP - AD Digital}

Daniela is the founder of AD Digital and today serves as SVP and is also the Marketing Director of SET. She is a guest speaker at key events related to the creation, management and distribution of content, to share her vision about the market, new business models and Trends for the industry.

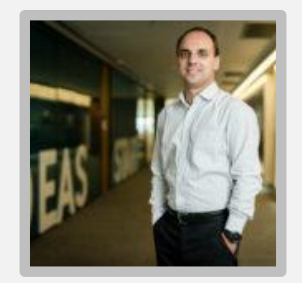

\section{Renato Citrini - Product Marketing Manager - Samsung}

Renato Citrini is Senior Product Manager for the Mobile Devices Division of Samsung Brazil since 2014. Prior to that, Citrini developed a career at Microsoft, working as a product marketing manager for six years, through the Office, Windows and Mobile Services divisions. The executive also toured a major trajectory in Motorola, Siemens and Ericsson. Electrical engineer graduated from USP

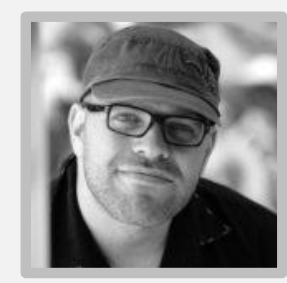

\section{Ricardo Laganaro, Director, $\mathrm{O} 2$ filmes,}

Ricardo Laganaro, director of $\mathrm{O} 2$ Films, has been specializing in new ways of telling stories since directing the film to the entrance dome of the Museum of Tomorrow in Rio de Janeiro. Since then, she has directed projects in $360^{\circ}$ and virtual reality, such as the video clip "O Farol" by singer Ivete Sangalo (most seen in the world in this format in 2016), a documentary series for the 20 years of SPFW, as well as advertising for clients such as MasterCard, Google and "O Boticário", among others, that total more than 60 million views. He was chosen by Oculus to be part of the project "VR For Good", where he directed the documentary "Step to The Line", filmed inside maximum security prisons in the USA. The film premiered as part of the official selection of the 2017 Tribeca Film Festival and has been gaining widespread worldwide repercussion, as well as being shared on the personal page of Facebook creator and CEO Mark Zuckerberg.

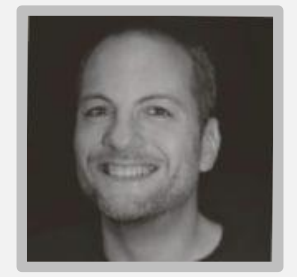

\section{Marcos Alves - Diretor de Ventures na YDreams Global}

Marcos Alves is Director of Ventures at YDreams Global, a Canadian company that combines sensory technology, integrated narratives and transformative design to enable the boldest ideas to be realized. He is responsible for idealizing, building and scaling new digital startups and products for global audiences in domains such as Virtual Reality, Augmented Reality, Internet of Things, Artificial Intelligence and Computer Vision. His next release will be Arkave VR, the first global network of arenas connected to Virtual Reality games. For more than 20 years, it has been working in the digital technology and business market, with Globo.com, TV Globo, ThoughtWorks Brasil and Dextra Digital in sales, management and delivery of digital products. 